\title{
Uma gestão escolar compartilhada entre humanos e encantados no Colégio Estadual Indígena Tupinambá Serra do Padeiro (CEITSP) ${ }^{1}$
}

Nathalie LeBouler-Pavelic

Doutora em Cultura e Sociedade pelo Programa Multidisciplinar de Pós-Graduação em (Pós-Cultura) da Universidade Federal da Bahia (UFBA) e em Antropologia Social e Etnologia pelo Institut Interdisciplinaire d'Anthropologie du Contemporain (IIAC), Laboratoire d'Anthropologie des Institutions et des Organisations Sociales (LAIOS) da Ecole des Hautes Etudes en Sciences Sociales (EHESS), França. É Pesquisadora associada do Programa de Pesquisas sobre Povos Indígenas do Nordeste Brasileiro (PINEB/UFBA) e do Justice and Indigenous People Rights (JUSTIP/EHESS) e membro sócia da Associação Nacional de Ação Indigenista (Anaí). E-mail: nathalie.leboulerpavelic@gmail.com https://orcid.org/0000-0002-1197-7146.

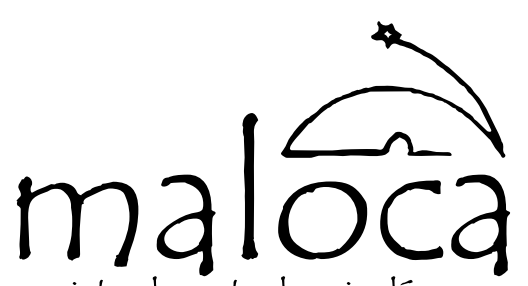
revista de estudos indígenas 


\section{Resumo}

Pretendo nesta apresentação evidenciar o papel dos encantados principais entidades da cosmologia tupinambá - como "agentes educativos" na educação indígena tupinambá de forma geral, mas também na educação escolar indígena, no âmbito do Colégio Estadual Indígena Tupinambá Serra do Padeiro (CEITSP), localizado na aldeia Serra do Padeiro, na Terra Indígena Tupinambá de Olivença. Apontarei, assim, para o fato de que a transmissão de saberes na Serra do Padeiro, tanto aquela de caráter informal quanto aquela sistematizada no âmbito da educação escolar indígena, é indissociável das ações dos encantados. Ao levar em consideração os trabalhos desenvolvidos tanto no Nordeste brasileiro quanto a literatura referente à Amazônia, evidenciarei como a gestão escolar do CEITSP é compartilhada com os encantados, uma vez que "trabalham", de várias formas, no/para o Colégio e de que forma além desta particularidade, o CEITSP atende também estudantes não indígenas. Chamarei então a atenção para as relações interétnicas entre Tupinambá e não indígenas, bem como entre humanos e encantados neste contexto.

\section{Résumé}

Dans cette présentation, j’ail'intention de souligner le rôle des encantados - principales entités de la cosmologie de Tupinambá - en tant qu “" agents éducatifs» dans l'éducation autochtone Tupinambá en général, mais aussi dans l'éducation scolaire autochtone, dans le cadre du Colegio Estadual Indígena Tupinambá Serra do Padeiro (CEITSP), situé dans la communauté Serra do Padeiro, dans la Terra Indígena Tupinambá de Olivença. Je signalerai donc que la transmission des savoirs à Serra do Padeiro, à la fois informelle et systématisée dans le cadre de léducation scolaire autochtone, est indissociable de l'action des encantados. Compte tenu du travail développé à la fois dans le Nordeste du Brésil et de la littérature concernant l'Amazonie, je montrerai comment la gestion scolaire du CEITSP est partagée avec les encantados, puisqu'ils «travaillent ", de diverses manières, dans / pour le Collège et de quelle manière, outre cette particularité, le CEITSP accueille également des étudiants non autochtones. J'attirerai ensuite l'attention sur les relations interethniques entre les Tupinambá et les non-autochtones ainsi qu'entre les humains et les encantados dans ce contexte.
Palavras-chave:

Tupinambá;

Educação;

Encantados; Relações

Interétnicas;

Nordeste.

Mots-clés:

Tupinambá;

Éducation;

Enchanté; Relations

interethniques;

Nordeste. 
A aldeia Tupinambá de Serra do Padeiro é uma das cerca de 20 localidades ${ }^{2}$ que integram a Terra Indígena (TI) Tupinambá de Olivença, que se estende por aproximadamente 47 mil hectares (ha), entre os municípios de Buerarema, Ilhéus, Una, São José da Vitória e Olivença no sul do estado da Bahia. Não obstante diversas fontes documentais atestem a presença histórica dos índios na região, apenas em maio de 2002 o governo brasileiro reconheceu oficialmente os Tupinambá e, em 2004, a Fundação Nacional do Índio (Funai) deu início aos procedimentos de identificação e delimitação da TI. No mesmo ano, os indígenas iniciaram o processo de "retomada de terras", ou seja, ações de recuperação de parcelas do território tradicionalmente ocupadas pelos indígenas, mas invadidas por não índios. Vale notar que, na condução do procedimento demarcatório, o estado vem desrespeitando os prazos determinados pelo Decreto $n^{\circ} 1.775 / 1996$, que dispõe sobre o procedimento administrativo de demarcação das terras indígenas. Em março de 2012, o processo foi encaminhado ao Ministério da Justiça (MJ) e, no mesmo ano, a assessoria jurídica do ministério pronunciou-se favoravelmente ao estudo realizado pela Funai.

Contudo, nem o então ministro da Justiça, José Eduardo Cardozo, nem seus sucessores assinaram a portaria declaratória da TI, mesmo após a proposição de três ações civis públicas pelo Ministério Público Federal (MPF), responsabilizando o Estado por desrespeitar a Constituição. Já em abril de 2016, o ministro Napoleão Nunes Maia Filho, do Superior Tribunal de Justiça (STJ), determinou a suspensão do processo demarcatório, respondendo a um mandado de segurança preventivo requerido em 2013 pela Associação dos Pequenos Agricultores, Empresários e Residentes na Pretensa Área Atingida pela Demarcação de Terra Indígena de Ilhéus, Una e Buerarema, negando a presença histórica dos Tupinambá no sul da Bahia ${ }^{3}$. Essa decisão foi anulada pelo mesmo STF em 14 de setembro de 2016. Em dezembro 2019, o ministro da Justiça Sérgio Moro, devolveu o processo de demarcação da TI à Funai visando impedir o cumprimento dos direitos indígenas.

É importante salientar que os Tupinambá vivenciam permanente criminalização, expressa na perseguição a várias de suas lideranças, impulsionada por indivíduos e grupos contrários à demarcação, amplificados por grandes meios de comunicação. $\mathrm{O}$ contexto atual é marcado por declarações anti-indígenas por parte do presidente da República, Jair Bolsonaro, e pela nomeação de representantes de seto-

\author{
1. Trabalho apresentado \\ na 32a Reunião de \\ Antropologia Brasileira. \\ Grupo de trabalho 2: GT \\ 2 - Amazônia e Nordeste \\ indígenas: por uma \\ etnologia transversa. 2020. \\ 2. O número de \\ localidades que compõem \\ a Terra Indígena de \\ Olivença tem apresentado \\ variações ao longo dos \\ anos em decorrência \\ da movimentação \\ sociopolítica do povo em \\ questão. \\ 3. Para mais informações \\ sobre a luta do povo \\ Tupinambá por \\ seu território, ver o \\ documentário Tupinambá \\ - O Retorno da Terra, \\ de Daniela Fernandes \\ Alarcon (disponível \\ em: https://vimeo. \\ com/126566470) e a sua \\ dissertação de mestrado \\ (2013) publicada como: \\ O Retorno da Terra: as \\ retomadas na aldeia Serra \\ do Padeiro, sul da Bahia, \\ São Paulo : Elefante, 2019.
}


res contrários aos direitos indígenas justamente para pastas que têm a atribuição de garantir tais direitos. Esse cenário tem sido terreno fértil para invasões de terras indígenas, assassinatos de lideranças e outras graves violações, conforme noticiado na imprensa, e como se verifica no caso tupinambá.

Os encantados, principais entidades da cosmovisão tupinambá, atuam em todos os âmbitos da vida social, econômica e política da comunidade. Apesar da situação de insegurança e da omissão/conivência do governo, os Tupinambá, orientados pelos encantados, vêm investindo continuamente no fortalecimento da aldeia em vários âmbitos. $\mathrm{O}$ presente artigo ${ }^{4}$ buscará evidenciar a atuação dos encantados principalmente no âmbito do Colégio Estadual Indígena Tupinambá Serra do Padeiro (CEITSP).

\section{"Encantado é um encante, algo que você não pode explicar"}

"Encantado ${ }^{5}$ é um encante, algo que você não pode explicar", avisa o cacique Babau à sua sobrinha Jéssica. Os encantados são entidades invisíveis que vivem em outras esferas ou aldeias paralelas. A princípio, não tiveram vida carnal, portanto, não devem ser confundidos com os espíritos de mortos. $\mathrm{Na}$ aldeia Serra do Padeiro, a formação rochosa de mesmo nome é considerada como sendo a morada dos encantados. Entre os Tupinambá, os encantados podem também ser chamados de caboclos ${ }^{6}$.

Segundo os Tupinambá da Serra do Padeiro, os encantados estariam presentes em outras culturas, com outros nomes. Os Tupinambá entendem que são filhos do caboclo Tupinambá e se organizam, religiosamente, em clãs. Conforme a explicação do cacique Babau:

Nós somos um povo de clã, mas não é clã de cada família, família A, família B, família C. Nós somos um povo de clãs espirituais [...] Nós [Tupinambá de Serra do Padeiro] somos o clã principal, nós somos o clã de Tupinambá [...] Beri, Gentil, esses comandam os clãs. E são todos de guerra e cada um tem um domínio. Um é sobre a onça como símbolo mais forte, outro sobre a serpente, sobre a cobra, outro sobre o domínio da mata, outro sobre o domínio das águas, outro sobre o domínio do vento. Cada um lidera uma força, um poder, uma determinação.

Enquanto seres de luzes, os encantados, mesmo tendo suas "moradias", podem transitar no tempo e nos espaços, assegurando, assim, de certa forma, a memória social do grupo. Eles podem expli-
4. Este artigo é baseado na minha tese de doutorado (2019): Aprender e ensinar com os Outros: a educação como meio de abertura e de defesa na aldeia Tupinambá de Serra do Padeiro (Bahia, Brasil). Todos os depoimentos apresentados neste artigo fora

5. Três trabalhos acadêmicos, com lentes diferentes, se debruçaram, especificamente, sobre a religiosidade da comunidade de Serra do Padeiro: as dissertações de Couto (2008) e de Ubinger (2012). Mais a dissertação - em andamento - de mestrado sobre o toré de Larissa Hohenfeld (Pós-Afro/UFBA). Mais recentemente, Jéssica Quadros (2018), também escreveu a respeito no seu trabalho de conclusão do curso de especialização em Estado e Direito dos Povos e Comunidades Tradicionais (UFBA). Além desses trabalhos mais específicos, todos os outros que foram desenvolvidos entre os Tupinambá acabam também referindo, uns mais do que outros, aos encantados, uma vez que são entidades que permeiam e atuam em todo o universo social, econômico e político tupinambá.

6. Conforme Simas \& Rufino (2018: 101), “o caboclo é o supravivente; aquele que está além da nossa concepção de vida biológica, filosófica e histórica. A condição do encante é a da experiência enquanto existência, superando assim as noções fechadas de vida e morte". 
car algo passado, ensinar alguma prática que esteja em desuso, algum remédio, indicar um espaço onde eram realizados rituais; ou seja, um leque infinito de saberes tradicionais. Ademais, transitando pelos diferentes espaços, podem prever acontecimentos futuros e avisar os $\mathrm{Tu}-$ pinambá de qualquer perigo prestes a acontecer. Neste sentido, Glicéria explica para sua sobrinha Jéssica que: "os encantados traçam uma rota em um espaço e uma geografia [...], eles trazem uma memória, uma história para a gente". Os encantados costumam se comunicar com o pajé da aldeia, seu Lírio, mas também em sonho ou através de pessoas, que podem ser o próprio pajé, pessoas iniciadas no culto aos encantados ou qualquer outra pessoa que os encantados escolherem. É interessante notar que, à diferença de outros povos, os Tupinambá da Serra do Padeiro não requerem a mediação de substâncias para a comunicação com os encantados, tais como a jurema ${ }^{7}$, entre outros.

No momento da manifestação, o médium permite o controle do seu corpo ${ }^{8}$ para que o encantado possa se comunicar com as pessoas, mediante avisos, conselhos, orientações, respostas, ensinamentos, reprimendas, entre outros, além de conversas aparentemente "triviais" que não deixam de emitir mensagens para quem sabe ouvir. Os encantados costumam também rezar, curar e proteger as pessoas. Essas várias modalidades de interação ocorrem por iniciativa direta do próprio encantado ou a pedido de uma pessoa, de forma reservada, ou em presença de outras pessoas. Os encantados costumam afirmar que estão "trabalhando" ou então "fazendo o serviço" devido ao qual tiveram que se manifestar. Costumam também ensinar cantos e sambar na roda do toré, na casa do santo, ou onde eles estiverem.

No entendimento Tupinambá, cada encantado pertence a uma nação de encantados e a seu lugar de moradia: encantado das matas, das águas, do ar. Tupinambá é o principal encantado. É, geralmente, ele que avisa da chegada de outros encantados que nunca se manifestaram na Serra do Padeiro. Além de Tupinambá, entre os encantados considerados como sendo da "mata", já se apresentaram na Serra do Padeiro: Sultão das Matas, Gentio, Rei das Folhas, Eru, Beri, Raio de Sol, Laje Grande, Boiadeiro, Lasca de Pedra, Quebra Corrente, Mina de Ouro, Botocudo, entre outros. Alguns encantados da mata possuem uma energia feminina, entre os quais estão a cabocla Jurema, a cabocla Velha e a cabocla de Pena. Entre os que moram nas águas,
7. A jurema pode se referir ao arbusto espinhoso nativo do Nordeste brasileiro, mas também à bebida com propriedades alucinógenas, feita com as suas raízes.

8. Segundo Simas \& Rufino (2018: 94), “[...] as performances corporais ou como preferimos chamar, as incorporações, nada mais são do que os modos de linguagem que exaltem a proeminência e as potências das sabedorias do corpo". 
manifestam-se, geralmente, Mãe d’Água/Janaina/Yemanjá e as Iaras, bem como os Martins, tendo estes uma energia masculina. Ainda se manifestam os Pretos Velhos e Cosme e Damião.

Existem, também, encantados que se manifestam sob a forma de animais e, contrariamente aos outros, não "falam" com as pessoas: onça, peixe marino, cobra caiana, gavião. Já a Caipora ${ }^{9}$, os Curupiras $^{10} \mathrm{e}$ o Saci ${ }^{11}$ são, conforme os Tupinambá, encantados que se encontram em outro estágio de vibração de energia e podem manifestar-se sob diferentes formatos. O encante é considerado como sendo o movimento dos encantados, que deixam um feixe de luz quando se deslocam de uma serra para outra, por exemplo.

Vale notar que a "mesma" entidade pode manifestar-se em várias pessoas, simultaneamente, ensejando que trabalhem conjuntamente; da mesma forma, encantados diferentes podem também trabalhar juntos. Além de ter uma moradia específica, de acordo com os Tupinambá, cada encantado possui um determinado estágio de vibração de energia - de jovem a velho - e formatos diversos de manifestação. Sendo assim, se um encantado se manifestar em várias pessoas simultaneamente, isso constituirá um indicador de ele fazer parte da mesma nação de encantados, mas pode ter vibrações diferentes, alguns com energia mais velha, outros mais jovem. Ao lhe ser perguntado como é possível reconhecer esses estágios de vibração, Glicéria me explicou que as pessoas que manifestam desde um determinado lapso de tempo conseguem desenvolver uma sensibilidade capaz de captá-las. Quando estão em presença de pessoas manifestadas, conseguem diferenciar o estágio de energia do encantado, "sentindo na pele" as vibrações. No caso de alguns encantados, seria mais "fácil" identificá-los, mesmo não sendo desenvolvido esse nível de sensibilidade. É o caso dos encantados com energias mais "novas", tais como Yemanjá "menina", Gentil "menino", entre outros. Os encantados podem passar, então, de um estágio a outro.

Os Tupinambá sabem como acolher cada encantado, mas, quando algum deles se manifesta pela primeira vez, o mesmo deverá apresentar-se e informar se precisa de algo ${ }^{12}$. Ademais, os encantados não são as únicas entidades não humanas com as quais se relacionam os Tupinambá. ${ }^{13}$ São Sebastião, por exemplo, é considerado como o padroeiro da aldeia e a festa em seu louvor - dia 19 de janeiro - é a celebração religiosa mais importante na comunidade. Ele não é consid-

\author{
9. Ver também Cascudo \\ (1998: 223). \\ 10. Ibid. \\ 11. Ver também Cascudo \\ (1998: 794). \\ 12. Por exemplo, os \\ Martins costumam \\ trabalhar com cigarros \\ e vinho; os Cosmes com \\ doces e brinquedos e as \\ Iemanjá com água de \\ cheiro. Já os Caboclos \\ costumam pedir folhas. \\ Contudo, os encantados \\ não precisam ser \\ "alimentados" com pratos \\ específicos tais como no \\ candomblé por exemplo, \\ os cantos do toré e as \\ orações os alimentam. \\ 13. Para mais \\ informações, ver a seção \\ “3.4 - A Serra do Padeiro \\ e sua Cosmologia” em \\ Couto (2008: 86).
}


erado um encantado, mas tal como é apresentado na Igreja Católica, o é como um santo. Segundo ouvi na Serra do Padeiro, ele é uma entidade protetora das aldeias, que viria somar forças com os outros encantados para aumentar o nível de energia. Ele é o padroeiro da aldeia, mas não é estritamente assimilado ao caboclo Tupinambá ${ }^{14}$.

Entre as outras entidades não humanas que manifestam na Serra do Padeiro, há ainda as pessoas que "não morreram, mas encantaram"15, tal como seu João de Nô, o pai de seu Lírio, que iniciou o culto aos encantados na aldeia ${ }^{16}$. Cabe notar que as pessoas que encantaram, ao se manifestarem - o que acontece com uma frequência menor à chegada dos encantados -, não costumam, geralmente, "trabalhar", mas vêm para abençoar ${ }^{17}$.

\section{Os encantados como "agentes educativos"}

Definir quem são os encantados não é fácil para os Tupinambá, uma vez que são sujeitos que praticam sua religiosidade e que se relacionam cotidianamente com eles. Logo também não o é para nós pesquisadores. Contudo, podemos tentar entender melhor de que maneira atuam em determinada situação. As pesquisas desenvolvidas entre os Tupinambá já evidenciaram a agencialidade desses seres enquanto atores políticos, principalmente no campo do reconhecimento étnico e na luta pelo território. Há também uma rica literatura etnográfica - inclusive no Nordeste - que analisa o papel da esfera espiritual dos povos indígenas no movimento indígena, com base no toré (Carvalho, 1994; Nascimento, 1994; Grunewald, 2005; Andrade, 2008). Foi também examinado o papel político do toré que, ao ser realizado entre os indígenas do Nordeste, contribui para o fortalecimento da identidade de cada um desses povos (Oliveira, 1999). Assim, o toré unifica ao mesmo tempo que distingue os povos indígenas na luta, cada um utilizando pinturas, trajes, cantos específicos. A depender da região do Nordeste e do povo indígena, o toré é também conhecido por porancim, awê, praiá, ouricuri, entre outras denominações. É interessante notar que entre os Tupinambá de Olivença, as designações toré e poramcim são utilizadas. Contudo, a comunidade da Serra do Padeiro refere-se quase sempre ao toré, enquanto as outras comunidades, sobretudo as do litoral, optam por usar porancim.
14. Já segundo Couto (2008: 103-104) a "tradição presente na Serra do Padeiro, no entanto, aponta para uma vertente da devoção a São Sebastião que parece estar ligada a processos de cura e purificação. De acordo com os Tupinambá da Serra do Padeiro, São Sebastião seria o 'médico de todas as aldeias', aquele capaz de livrá-los de enfermidades e torná-los firmes em momentos de adversidade, tanto ligadas à saúde do corpo quanto da alma, que porventura os pudessem abater em sua labuta diária."

15. Em outras circunstancias, "baixar ar de mortos" de pessoas que não encantaram é considerado como algo ruim entre os Tupinambá, algo prejudicial à pessoa e que precisa ser retirado. Pode acontecer se, por algum motivo, a pessoa está "fraca”, não se cuidou espiritualmente ou passou perto de algum córrego de água, entre outras razões possíveis.

16. Para informações detalhadas sobre o início do culto aos encantados na Serra do Padeiro, ver a trajetória de João de Nô, pai de Seu Lírio em Couto (2008: 127) bem como a sua biografia elaborada por Daniela Fernandes Alarcon, no site do Projeto "Os Brasis e suas memórias: os indígenas na formação nacional", disponível em: <https:// osbrasisesuasmemorias. com.br/biografia-joaode-no/>.

17. Além de seu João de Nô, cuja manifestação tive a oportunidade de presenciar algumas vezes, há relatos de que já se 
Em outros contextos etnográficos, analisou-se também a atuação de entidades não humanas em situações de reconhecimento étnico e direito territorial, tais como os trabalhos de Surallés (2017) desenvolvidos entre os povos Candoshi e Shiwilu, na Amazônia peruana. Em uma sessão dos "Seminários Perspectivas Comparativas sobre os Direitos dos Povos Indígenas", coordenados por Bellier e Ricaud, em novembro de 2018, na École des Hautes Études em Sciences Sociales (EHESS), Glicéria, Jéssica e eu mesma tivemos a oportunidade de refletir com o antropólogo Surallés sobre o tema "Direitos dos povos indígenas: até uma extensão dos direitos humanos para os não-humanos?”. No trabalho apresentado ${ }^{18}$, Surallés evidenciou o paradoxo entre o reconhecimento da autodeterminação dos povos indígenas - e dos seus direitos associados, tais como o direito territorial - por parte da Declaração das Nações Unidas sobre os Direitos dos Povos Indígenas (UNDRIP), em 2007, e o fato de que, para esses povos, o território não é apenas habitado por eles: eles coabitam, como vimos, com diversos tipos de seres não humanos. Sendo assim, Surallés produz uma instigante discussão sobre a extensão dos direitos dos povos indígenas para as entidades não humanas que povoam seus territórios. $\mathrm{Na}$ análise elaborada para o caso dos dois povos mencionados, são as relações sociais estabelecidas entre os povos indígenas e essas entidades que lhes permitiriam exercer seus direitos enquanto "povos indígenas" no direito internacional. A partir de uma perspectiva histórica, ele mostra que ocorreu uma mudança generalizada na consideração da natureza de um sujeito de direito. Se no século XVI não considerar os povos indígenas como seres humanos permitiu criar textos de lei que privaram esses povos dos seus direitos, no século XXI discute-se a necessidade de considerar os não humanos como pessoas ou, pelo menos, entidades detentoras de direitos.

Na referida sessão dos Seminários, a partir do caso da comunidade da Serra do Padeiro, Glicéria discutiu sobre o papel político dos encantados na luta pela demarcação do território, e Jéssica apresentou o já referido TCC (Quadros, 2018), no qual ela analisa a possibilidade de união entre povos tradicionais e suas respectivas entidades não humanas na luta pela garantia dos seus direitos, respeitando suas diferenças.

Apontaremos, assim, para o fato de que a transmissão de saberes na Serra do Padeiro, tanto aquela de caráter informal quanto manifestaram Magno e Jandira - Ana Zilda Ferreira da Silva - uma das filhas de João de Nô e de uma indígena conhecida como Maria Evangelista. Para mais informações a respeito de Jandira, ver Alarcon (2013: 211-212).

18. Ibid. 
aquela sistematizada no âmbito da educação escolar indígena, é indissociável das ações dos encantados, que passam a ser "agentes educativos".

\section{"A escola é de Tupinambá": consultas, avisos, limpezas e proteções}

No âmbito do Colégio Estadual Indígena Tupinambá Serra do Padeiro (CEITSP), a comunidade busca atender aos pedidos dos encantados. Entendo, assim, que a gestão desenvolvida é uma gestão escolar compartilhada, uma vez que os encantados "trabalham", de várias formas, no/para o Colégio. Na hierarquia do CEITSP, os encantados estão acima da diretora Magnólia Jesus da Silva, ela mesma estando abaixo de seu Lírio, seu pai e pajé da comunidade, e do cacique Babau, seu irmão, enquanto representante político. A diretora explica que:

Tenho muita fé em Deus e muita fé nos encantados. Muita mesmo, porque tudo que a gente tem aqui hoje e que conseguimos é graças a Deus e aos encantados que nos orientam, e também não desobedeço. Se os encantados chegarem e me falarem: "Magnólia é assim, assim, assim...", eu sigo o que eles falam. Não desobedeço, de jeito nenhum, e faço as coisas mesmo porque gosto e tenho prazer de fazer.

Antes de tomar qualquer decisão relativa aos assuntos cotidianos, a comunidade costuma consultar o pajé. Tal procedimento acontece também para assuntos vinculados à educação escolar. Antes do início de cada ano letivo, Magnólia "manda olhar a escola", ou seja, pede para seu pai "ver" a situação da escola para o ano que se iniciará, e permanece atenta às orientações: "mando olhar a escola, mando olhar os funcionários, mando olhar como vai ser esse ano na organização. Todo ano faço isso. Se o pajé pedir para fazer qualquer coisa, faço: limpeza, comprar algum banho ${ }^{19}$, tudo eu faço".

O Colégio trabalha com alguns professores não indígenas, por não dispor ainda de professores indígenas suficientes para atender as exigências do governo do Estado em termos de capacitação. Eles são encaminhados pela Secretaria de Educação, mas, antes de começarem a trabalhar, a diretora do CEITSP pede para o pajé dar uma olhada para ver "se vai dar certo ou não, se é uma pessoa de má intenção ou não [...] e se eles [os encantados] virem que há algum perigo, avisam e a gente não chama”. A decisão final respeita sempre a vontade dos encantados.
19. Além dos banhos de folhas naturais, pode acontecer que os Tupinambá de Serra do Padeiro comprem "banhos prontos" em uma loja de produtos esotéricos na cidade. Quando perguntei qual era a necessidade de comprar esses tipos de banhos uma vez que eles dispõem de todas as folhas necessárias para uma preparação natural, foi-me respondido que é porque a limpeza tem que descarregar também os "trabalhos" feitos por pessoas de fora. Portanto, os banhos de folhas limpam e protegem mais por dentro (divergências na comunidade, falta de comunicação etc.) enquanto os "banhos prontos" permitem o descarrego de efeitos negativos externos (por exemplo, não finalização da construção do prédio escolar, contratação de professores, etc.). 
Além das consultas, há os avisos e orientações procedentes dos encantados mediante manifestações ou sonhos. As primeiras ocorrem, geralmente, durante os rituais, onde a presença deles é esperada. Mas podem também ocorrer em qualquer outro momento, fora dos rituais, onde a sua presença não é esperada, embora não surpreenda ninguém da comunidade. Nas reuniões da Associação dos Índios Tupinambá da Serra do Padeiro (AITSP), as referências aos encantados são comuns, e recebidas com circunspecção, como o comprova o fato de serem, na sequência, registradas em atas. $\mathrm{Na}$ ata de 26 de março de 2017, consta o registro: “[...] a nossa casa é governada pelo Tupinambá”. As reuniões da AITSP são conduzidas pelo cacique Babau, com intervenções de pessoas diversas internas à comunidade ou externas, quando houver (representantes do governo, de alguma instituição, indígenas de outros povos, entre outros). São momentos de reunião de toda a comunidade, incluídos, portanto, as crianças e dos jovens. O pajé não costuma participar diretamente das reuniões, a menos que tenha algum aviso importante a ser repassado, tal como aconteceu na reunião do dia 3 de setembro de 2017. Ele comunicou ao cacique Babau que iniciaria a reunião e assim o fez, puxando um canto ao som do maracá. O caboclo Tupinambá rapidamente se manifestou (nele) e deu um aviso para os professores. Explicou que representantes do governo do Estado viriam para fazer perguntas referentes ao desenvolvimento da educação escolar indígena na aldeia e ressaltou a importância de se reforçar o trabalho com a cultura. Quando o pajé voltou a si, o cacique Babau chamou a atenção para o perigo de não trabalharem com sua cultura. Ele avalia que há indígenas no Brasil - chamando a atenção para alguns professores do CEITSP - que teriam vergonha de se identificar como tal "somente para o outro não falar mal dele", buscando, assim, "se igualar ao outro", isto é, o não indígena.

Em concordância com as palavras do cacique Babau, Benites (2009: 52) avalia que, entre os Kaiowá do Mato Grosso do Sul (MS), as lideranças políticas (mburivicha) e religiosas (ñanderu) também enxergam a valorização da cultura do não índio (Karai reko) como fonte de perigo. Em um depoimento ao autor, uma rezadora compartilhou sua preocupação ao ver as novas gerações "[...] imitar a cultura ou ser do não-índio" e ter "vergonha de ser Kaiowá". Benites informa que tais queixas são comuns entre os anciões Kaiowá que continuam praticando os rituais tradicionais. De acordo com o cacique Babau, o profis- 
sional indígena que está voltado para a cultura se importa primeiro em cumprir as recomendações do pajé e do cacique antes de fazer o que o "branco quer". Ao contrário, os profissionais indígenas que não estão voltados para a cultura, não atentam para as orientações dos encantados, do pajé e do cacique e priorizariam as orientações do governo do Estado em relação à educação escolar indígena. Ao contestar sua origem, estariam colocando em perigo a preservação da cultura e enfraquecendo, ao mesmo tempo, as lideranças das aldeias. "Hoje, em muitas aldeias, se enfraqueceu a educação, a saúde, mas não é porque os índios ficaram fracos, é porque [...] resolveram puxar para outros caminhos". Aqui, o cacique Babau está se referindo aos indígenas que se tornaram "crentes". Na ata da reunião da AITSP do dia 26 de março de 2017, há o registro de que o cacique Babau "falou que os encantados querem seguir os rituais e não queriam interferência de nenhuma outra religião".

$\mathrm{Na}$ Serra do Padeiro, os poucos professores que se tornaram crentes fazem parte, na maioria, de um tronco familiar. Não escutei nenhum deles expressar preconceito contra a religiosidade tradicional, mas percebi que alguns deixaram de participar do toré e de festas religiosas da comunidade, tais como a festa de São Sebastião, os carurus, a festa da bandeira do Divino Espírito Santo ${ }^{20}$, entre outras. Essas pessoas participam apenas dos rituais realizados no âmbito da educação escolar indígena, deixando de cantar algumas vezes ou de receber defumador e banhos. No início das mobilizações tupinambás, todos eles estavam muito engajados, participavam das retomadas, dos toré e festas religiosas, trajavam-se, cantavam para os encantados, recebiam banho de folhas e defumador. Os professores indígenas "crentes" tendem a trabalhar mais em sala de aulas o conteúdo dos livros didáticos. Conversei com uma das professoras identificada como "crente", sobre o fato de se trabalhar a cultura diferenciada em sala de aula, e ela compartilhou seu receio desse tipo de trabalho não servir para a aprovação nos exames de ingresso na universidade.

Tal pensamento evidencia que o processo de descolonização das mentes e, por consequência, de instituições como a escola, representa ainda um desafio. Mesmo no marco das modalidades de educação escolar indígena, acatar todas as diretivas do governo do Estado para o funcionamento do Colégio contribui, paradoxalmente, para desqualificar o caráter diferenciado de tal educação. Quando a comunidade
20. A festa da bandeira do Divino Espírito Santo acontece cada ano no dia de Pantecostes. Os romeiros percorrem, a pé, Olivença, a sua zona rural e os municípios dos arredores durante semanas, carregando duas bandeiras vermelhas com uma imagem de uma pomba branca no seu centro e também no topo, ornamentada de flores e fitas de votos coloridas. As esmolas recebidas contribuem para a organização da festa do Divino na sede de Olivença, frente à igreja de Nossa Senhora da Escada. Para mais informações sobre a festa, ver Costa, E. (2013). Tive a oportunidade de participar duas vezes da festa da bandeira do Divino Espírito Santo, em 2016 e em 2018. Em 2016 acompanhei parte da peregrinação em algumas aldeias do litoral e em 2018, acompanhei toda a peregrinação (quatro dias) na aldeia Serra do Padeiro. 
não segue "os padrões dos não índios", o modelo adotado torna-se um incômodo. A comunidade avalia que os sistemas desenvolvidos pelo governo do estado são também uma forma de "fiscalizar" as escolas: ao mesmo tempo que exigem o diferenciado, limitam o desenvolvimento de tal educação. A comunidade procura, então, seguir as orientações dos encantados em todos os âmbitos da esfera sociopolítica da aldeia.

Respeitar as orientações dos encantados significa também realizar algumas medidas de "limpeza" e de proteção para garantir o bom funcionamento das atividades escolares. Para assegurar proteção, além dos altares da casa do santo e altares pessoais, há altares menores em vários espaços do colégio, tais como a secretaria, a biblioteca, a sala dos professores e a cozinha. Como não dispõem de mesas específicas, elas são improvisadas com o mobiliário escolar. Os quatro locais reúnem imagens pequenas de Cosme e Damião, dois potinhos de barro, dois potinhos brancos de porcelana - os quatro cheios de doces -, duas garrafinhas de mel, algumas moedas espalhadas, um vaso de flores e velas. Além desses elementos, o altar da biblioteca tem também uma imagem de Iemanjá. Os altares são deixados aos cuidados dos funcionários.

Antes do início do ano letivo, uma "limpeza" é realizada para purificar todos os espaços do colégio e "fazer desenrolar as coisas" Presenciei a limpeza feita por Glicéria e Maria Erenita no dia 26 de janeiro de 2018, sob o olhar atento de dona Maria. "Vou limpar tudo", disse Glicéria, vestida com uma saia longa branca usada nos trabalhos espirituais. Na casa do Santo, Dona Maria a orientou para a troca da saia por uma outra "de trabalho", mais velha, ou uma tanga, para não sujar a saia nova que ela mesmo tinha confeccionado. Isto feito, acompanhadas de Ory, filho menor de Glicéria - que, no momento, não tinha ainda dois anos -, descemos em direção ao local da construção do prédio escolar para buscar ramos de alecrim do campo para a preparação a ser usada na limpeza da escola. Glicéria cortou alguns ramos e entregou uma quantidade para Ory, pedindo-lhe para sobraçá-los enquanto colhia outros. Como veremos nas seções seguintes, as crianças aprendem vendo e fazendo desde que nascem, e isso mostra o quanto a educação está para além das paredes do âmbito escolar.

Retornamos à casa do santo, Glicéria deixou Ory com uma prima para se concentrar na limpeza. Os trabalhos de "descarrego" e de purificação, quer sejam de pessoas ou locais, exigem uma grande concentração e precaução, inclusive, neste caso, para que a fumaça provocada
21. Fora do âmbito escolar, assisti também à limpeza de uma retomada realizada por Glicéria. Ela é chamada também para realizar limpeza espiritual de casas ou de roças. 
pela pólvora não atinja as pessoas ao redor. Junto com Maria Erenita, então secretaria do Colégio, continuaram a preparação dos produtos de limpeza: água com "banho pronto" e folhas, incenso e pólvora ${ }^{22}$. Após ter colocado incenso para queimar, Glicéria começou a varrer os diferentes espaços do colégio com os ramos de folha de alecrim do campo e, na sequência, distribuiu a pólvora em três cantos - perto da porta de entrada, no meio e no fundo. Todos os trabalhos realizados em um local fechado devem ter suas portas e janelas abertas. A combustão da pólvora veicularia informações sobre o estado de "carrego" do local. Se a pólvora demorar de queimar é sinal da presença de muitas energias “ruins”. Após a fumaça desaparecer, Maria Erenita passou um pano com a preparação feita - água, folhas e banho de descarrego pronto -, começando de dentro para fora e, mais uma vez, de fora para dentro. A queimação da pólvora não costuma provocar um odor agradável, e passar um pano "cheiroso" finaliza o trabalho de limpeza.

Além dos espaços do Colégio, pode haver a necessidade de proceder a uma limpeza dos carros escolares. Já escutei uma mãe lembrar que um encantado tinha avisado para fazer uma limpeza no caminhão para evitar problemas e, assim, garantir a segurança dos estudantes e do motorista. Os trabalhos de limpeza podem também ser feitos pelos próprios encantados, como veremos, logo a seguir, na jornada pedagógica do início do ano letivo de 2018.

\section{"A jornada pedagógica está por conta dos encantados"}

A pré-jornada pedagógica 2018, promovida pelo governo do estado para as escolas e colégios da rede estadual de ensino do NT5-Itabuna, realizada em 29 de janeiro de 2018, durante uma manhã, no Colégio Modelo dessa mesma cidade, reuniu gestores, coordenadores pedagógicos, professores e técnicos. Acompanhei Magnólia na ocasião, enquanto representante do único colégio estadual indígena do NT5. A temática apresentada para 2018 foi "Aprendizagens e Territórios: Novos Rumos para a Educação do Século 21", focando sobre os territórios de identidade onde os colégios estão inseridos. Durante o encontro, além dos representantes da SEC darem informações diversas referentes aos recursos repassados pelo governo federal e sobre datas importantes, entre outras, foram dadas orientações para a organização das jornadas
22. Fora das limpezas, as únicas outras vezes que presenciei o uso da pólvora em trabalhos rituais entre os Tupinambá foi durante os trabalhos de fechamento de corpo. 
pedagógicas nas unidades escolares. Trata-se de um dos momentos mais importantes do calendário escolar, uma vez que são planejadas as ações e as metas a serem desenvolvidas durante todo o ano.

Tal como orienta a temática escolhida para o ano de 2018, as unidades escolares deveriam organizar a jornada pedagógica e seus decorrentes projetos para o ano escolar de acordo com suas realidades. Pretendo aqui dar um exemplo mais detido sobre a atuação dos encantados enquanto "agentes educativos" e de que maneira eles e os Tupinambá "trabalham" juntos para o funcionamento e o desenvolvimento das atividades escolares. Notem que, neste contexto, o verbo "trabalhar" diz respeito, para os Tupinambá, ao exercício das funções de sua profissão - no caso, enquanto corpo docente do colégio -, mas também à assunção de obrigações rituais vinculadas ao culto dos encantados. Eles também, como já mencionamos, dizem e cantam que "trabalham" ou que chegam para "fazer o serviço". Humanos e não humanos trabalham, então, para atingir o mesmo objetivo: aqui, compartilhando a gestão do CEITSP para que o ano escolar seja próspero, que atenda o projeto mais amplo da comunidade em busca de maior autonomia.

Na reunião mensal da AITSP do domingo, 4 de fevereiro, Magnólia, a diretora do CEITSP, convidou a comunidade para participar da Jornada Pedagógica do CEITSP, que aconteceu entre os dias 7 e 9 do mesmo mês ${ }^{23}$. Além dos funcionários, de forma geral, ela solicitou a presença dos "guardiões da cultura" - ou seja, os anciões -, bem como do pajé e do cacique. Os jovens também foram convidados para, além da participação enquanto estudantes, ajudarem na organização e auxiliar os encantados. $\mathrm{Na}$ ocasião, Magnólia explicitou que os encantados estariam à frente da abertura da Jornada Pedagógica e que, se havia horário marcado para iniciar as atividades, não havia para terminar, dependendo das orientações deles. Magnólia pediu também ajuda para cuidar da alimentação durante os três dias, para que as auxiliares de cozinha pudessem participar do evento.

No decorrer desse primeiro dia da Jornada Pedagógica, o encantado Sultão das Matas manifestado no pajé, de pé próximo ao altar da casa do santo, com um ramo na mão direita, começou a falar. Os outros encantados manifestados em outras pessoas permaneceram em silêncio, dando alguns passos no meio da roda do toré. As outras
23. Magnólia preferiu mudar a data para que a abertura da Jornada Pedagógica começasse um dia de quarta-feira, considerado - junto com sexta-feira - um bom dia para os trabalhos espirituais na comunidade e então para que os encantados abrissem o evento. 
pessoas, de pé, escutavam, com os braços ou as mãos dispostos em cruz, na frente ou atrás, com o olhar direcionado para os encantados ou para o chão.

[...] as coisas ruins que vêm no mundo são curadas com as folhas [levantou o ramo]. As folhas e a água [...] trazem tudo para a saúde, é onde tem as forças de Deus. [...] Só Deus tem a verdade e a força de todos os encantados. Esse ano, vai ser assim: vai ter sol e chuva, agora o sol é quente. Na hora que esquenta, ele esquenta, na hora que chove, chove mesmo [...]. Entonces a gente pede as forças de Deus para [...] abrir a mente de cada um de vocês [...]

A diretora do CEITSP, Magnólia, aproveitou a fala do encantado e disse:

Eu peço a todos vocês, os encantados, que abrem a mente de cada um para a prosperidade, para a sabedoria, para o desenvolvimento, para a saúde de todos e que todos tenham a mente aberta. $\mathrm{E}$ que livrem a gente da inveja, da usura, da doença, da ambição. Tirem isso do meio de nós porque nós queremos a união, a paz, a sabedoria e a felicidade no meio da gente. Eu quero que vocês nos ajudem. Vocês já ajudam, mas peço a vocês que nos ajudem bem mais.

Sultão das Matas respondeu, insistindo sobre a importância das folhas ${ }^{24}$ :

[...] Foi Deus que deu as folhas para curar. Só o que vai curar é a folha porque são as coisas naturais. Só Deus que faz vencer as leis e a força dos Encantados para que ninguém adoeça [...]

O Encantado de seu Lírio permaneceu de pé, com o ramo de folhas na mão direita, enquanto as pessoas retomam a batida do maracá, ainda no mesmo lugar. Os encantados continuaram dando passos no meio da roda, alguns acompanhando com movimentos a letra dos cantos, direcionados agora para o Caboclo Gentio, não mais para Sultão das Matas:

- Gentio, Gentio / Caboclo forte sou eu / E essa força que eu tenho / Foi Deus que me deu / Foi o céu que me deu

- Ô balança meu Gentio / para apanhar folhas cheirosas / Ô balança meu Gentio / para brincar na aldeia nova

- O caboclo Gentio não pisa no chão / ele voa que nem gavião / cessou, cessou, que nem gavião / peneirou, peneirou que nem gavião

O Caboclo Gentio manifestado em seu Lírio puxou outro canto e todos acompanharam:

- Eu vi o sol sair / eu vi a lua nascer / na aldeia de Canabrava / Eu vi o Gentio gemer / Eu não tenho nem pai, nem mãe / nem quem se doa por mim / Minha mãe é do céu / Meu pai é o senhor do Bonfim
24. Alguns professores indígenas tornaram-se evangélicos, o que explica a insistência do encantado com o uso das folhas, de não virar as costas para as coisas da natureza e muito menos faltar com o respeito aos encantados. 
A abertura oficial encerrou já no início da tarde, quando os últimos encantados foram embora. Alguns médiuns ficaram cerca de quatro horas manifestados. Após o almoço, a diretora relembrou que todos deviam comparecer para o segundo dia da Jornada Pedagógica, que seria dedicada à mesa redonda com os anciões, pela manhã.

Os encantados costumam ser assistidos por humanos. O grupo de jovens tem grande responsabilidade para com eles, atentando para que nada lhes falte. Os Tupinambá costumam dizer que são 80 \% espírito e $20 \%$ matéria. As crianças são educadas para entender o mundo espiritual e o mundo material, no intuito de viverem em harmonia na terra, sabendo que o mais importante é a alma e não o corpo. O cacique Babau explicou, no Encontro "Luta pela terra e educação na Terra Indígena Tupinambá de Olivença” ${ }^{25}$, que isso explica a sobrevivência dos Tupinambá ao longo dos séculos: "Nós conseguimos sobreviver em qualquer situação, e conseguimos ser qualquer coisa, mas só não deixamos de ser Tupinambá".

Os conhecimentos espirituais são fundamentais para que a criança possa desenvolver-se com todas as aptidões necessárias à sua identidade tupinambá. Se os Tupinambá são mais espírito do que matéria, eles se organizam, em torno da terra, uma vez que entendem ser o seu dever dela cuidar para os encantados. Não se consideram, portanto, donos da terra, mas parte dela.

Para a Jornada Pedagógica de 2018, a SEC orientou a realização de uma mesa redonda sob o tema "Melhoria da aprendizagem dos/ as estudantes, na perspectiva de ambientes contextualizados no Século XXI e da educação no território e sua Economia", com a participação de todos os segmentos da unidade escolar. Para essa mesa, a diretora convidou os anciões da comunidade, no intuito de ouvi-los sobre a escola que "eles querem" e o que pretendem para os netos e demais parentes que ali estudam.

Entre os Tupinambá, a oralidade, cuja importância foi ressaltada nas orientações dos anciões para o Colégio, é imprescindível nos processos de educação. É mediante a oralidade que se transmite e se preserva a memória social do grupo. Ao procurar saber se as crianças e jovens estão conscientes dessa forma de transmissão de saberes, quando em entrevistas ou em conversas, perguntei-lhes o que consideram como educação tupinambá fora da sala de aula, e muitos me
25. O Encontro ocorreu entre 24 e 27 de novembro de 2016, na aldeia da Serra do Padeiro, organizado por Glicéria Tupinambá, Daniela Fernandes Alarcon e por mim. 
responderam: as histórias contadas pelos anciões. Maguinho, filho de Mágnolia, comentou que um dos momentos que considera de muita aprendizagem

é quando senta todo o mundo na beira do fogo e meus avós começam a contar os casos de antigamente, do meu avô, de como começou a luta e isso é o que acho o mais importante, porque é uma coisa concreta que eles estão repassando para a gente. Eu acho que é ali aonde a gente mais aprende.

A tradição oral, através da voz manifestada dos encantados e da oralidade dos anciões, favorece então as relações sociais e a circulação de conhecimento e informações.

\section{"Aqui é variado, têm alunos de tudo que é lugar": uma edu- cação duplamente diferenciada}

Comunidade e encantados como um todo participam diretamente da elaboração e reelaboração dos objetivos do Colégio. Cabe aos funcionários sistematizar e aplicar as orientações. Construir uma educação que permita aos jovens crescer sabendo andar dentro e fora da comunidade, e assim desenvolver os projetos da aldeia com vistas a lograr mais autonomia, é a meta de todos que fazem funcionar o CEITSP.

Mais precisamente, o CEITSP funciona em três turnos, atendendo a educação básica - que compreende a educação infantil (creche e pré-escola), o ensino fundamental ( $1^{\circ}$ ao $9^{\circ}$ ano) e o ensino médio ( $1^{\text {a }}$ a $3^{a}$ série) -, o Programa Nacional de Integração da Educação Profissional com a Educação Básica na modalidade de Educação de Jovens e Adultos (Proeja) e o curso técnico em agroecologia. O turno matutino atende o ensino médio e o curso técnico em agroecologia; o turno vespertino, a educação infantil e o ensino fundamental, e o turno noturno, o Proeja. A creche está à disposição nos três turnos.

Em 2018, o corpo discente do CEITSP constava 350 estudantes, sendo 177 do sexo masculino e 173 do sexo feminino; entre eles, 177 eram não indígenas, ou seja, basicamente a metade. Nesses últimos anos, o número de estudantes matriculados no CEITSP variava em torno de 400 estudantes.

Além de ser diferenciado em decorrência da sua proposta pedagógica étnica voltada para os interesses indígenas e, especialmente, para os interesses Tupinambá, o CEITSP tem a particularidade de 
acolher também os "Outros", ou seja, estudantes não indígenas provenientes de acampamentos e assentamentos de sem-terra, bem como famílias de trabalhadores rurais que vendem sua força de trabalho por "empreita" em fazendas da região. Nesse sentido, estaríamos diante de uma proposta de educação escolar interétnica que se propõe a incluir não índios em situação social estruturalmente próxima à dos índios, um Outro próximo (Agier; Carvalho, 1994: 111). Trata-se de uma proposta que parece contemplar, complementar e relacionar, questões afeitas aos conceitos de etnicidade e de classe social, e que podem, de forma inovadora, apontar para alternativas de convívio étnico-social pouco mais abrangentes e generosas. Outras experiências similares, nacionais e internacionais, são conhecidas.

A educação escolar, entre os Tupinambá, similarmente a outros povos indígenas, é considerada como um ato político. Os estudantes não indígenas são também formados e capacitados à luz da chamada luta indígena uma vez que estão recebendo uma educação escolar indígena. A legislação nacional estabeleceu as bases da educação escolar indígena, ao garantir uma educação escolar específica, diferenciada, intercultural, bilíngue/multilíngue e comunitária. Esse conjunto de instrumentos legais representa um avanço no que diz respeito ao reconhecimento dos direitos dos povos indígenas, particularmente no caso dos Tupinambá, historicamente relegados à invisibilidade. Para o cacique Babau, o povo brasileiro, em geral, sofreu e sofre:

uma lavagem cerebral dentro das escolas "militarizadas". O Brasil tem uma escola militarizada que ensina a ser obediente e concordar com tudo o que existe no país e não reagir, como se o país não fosse nosso, como se o dinheiro não fosse nosso, que está sendo roubado no país.

Contrariamente a esse modelo de escola "militarizada" ou ideologicamente enquadrada, a proposta do projeto político-pedagógico do CEITSP é promover uma educação "diferenciada, de qualidade e pela interação das pessoas, para um ensino de qualidade e respeito mútuo entre as pessoas" (Escola Estadual Indígena Tupinambá Da Serra Do Padeiro, 2014: 5), capaz de favorecer o "resgate [d]a cultura, [a] luta pela terra e [os] cuidados ambientas" (2014: 9). Nesse sentido, não obstante o CEITSP venha trabalhando para manter viva a memória coletiva do povo Tupinambá, fortalecendo sua identidade e, consequentemente, 
mobilizando politicamente os estudantes, encampou, simultaneamente, o desafio de trabalhar para acolher o "Outro" e contornar os preconceitos.

A violência do estado brasileiro ao não demarcar o território tupinambá, viola os direitos dos indígenas mas também dos não indígenas, principalmente aqueles oriundos de estratos sociais mais pobres. As tensões e conflitos que, frequentemente, eclodem entre os Tupinambá e segmentos regionais poderiam ter-se estendidos para os pequenos produtores, trabalhadores rurais e sem-terra, e instrumentalizado como mais um pretexto para não demarcar o território indígena. Contudo, conscientes da privação de direitos experimentada por esses não indígenas - consideramos aqui as privações territorial e educacional -, e de que eles não são seus inimigos, os Tupinambá acabaram abrindo-lhe as portas da educação escolar indígena, o que requer observar uma série de precauções por parte dos indígenas.

Como disse uma estudante indígena: "aqui é variado, têm alunos de tudo que é lugar, tudo que é tipo". "[...] tem gente de toda cultura, de toda religião, de tudo assim... é legal porque é diferenciada a escola, é variada. É como se fosse uma escola fora só que indígena”, afirma outra, mas ambas parecem satisfeitas com a pluralidade. A recepção dos não indígenas se dá mediante a sua introdução às regras do colégio e às peculiaridades da educação escolar indígena.

Selecionar e sistematizar elementos da educação tupinambá para a educação escolar indígena não é tarefa fácil para os professores, muito menos ao ter que tomar em consideração a presença dos estudantes não indígenas no Colégio. Previamente à matrícula, os estudantes são avisados de que aquele colégio não é um colégio público "comum" já que receberão uma educação escolar indígena. A maioria prossegue com os trâmites de matrícula sem saber exatamente o que isso significará na prática, mesmo se a diretora e as secretarias deixarem claro que o currículo será composto por disciplinas diferenciadas e que as demais disciplinas serão trabalhadas a partir das características da comunidade.

Vale lembrar, ademais, que os encantados pediram para que antes de começar a aula propriamente dita, os corpos docente e discente - incluídos os estudantes não indígenas - se reunissem para rezar e cantar. E assim acontece a cada dia, no início dos turnos matutino e vespertino. Não se trata exatamente de um toré, mas de uma reza de 
abertura para propiciar as atividades escolares, não sendo realizado no turno noturno por se tratar de um turno mais curto (18:30 às 21:30). Magnólia informa a todos, em várias ocasiões, que "o toré é aula", deixando claro que os ausentes seriam penalizados com faltas. A roda do toré matutina de abertura organiza-se ao redor do fogo, uma grande roda devido ao número maior de estudantes. Já a vespertina organiza-se em duas rodas, dispondo-se as crianças menores ao meio. Todos se dão as mãos e começam por recitar as orações (três Pai Nossos, três Ave Marias, três Santa Marias), entoando também três cantos para os encantados da escolha dos estudantes ou professores ${ }^{26}$. Todos se cumprimentam, nutrem-se de forças para bem iniciarem os trabalhos do dia, havendo também espaço para avisos coletivos. Há uma deliberada preocupação em valorizar a oralidade e reforçar a identidade. Para os estudantes não indígenas, trata-se de uma prática totalmente diferente do que tiveram oportunidade de conhecer em outras escolas públicas não indígenas. Alguns deles, mesmo avisados com antecedência, chegam a pedir para não participar devido à religião que professam, pedido em geral formulado pelos "crentes". A diretora explica, invariavelmente, que não pode acatar tal pedido, uma vez que a realização do toré é considerada como uma aula e que é recomendação dos encantados, a quem o Colégio pertence. Relativamente a essa disposição, uma mãe evangélica moradora de assentamento me comentou:

Eu falei [para a filha], "qualquer coisa, fica lá, fica na sua. Deixa eles cantar, você fica só ouvindo porque cada um tem sua religião, cada um segue o que for". Não tenho discriminação. Queria até chegar a falar com a direção mas depois deixei para lá [para pedir que a filha não participasse].

Ao observar, quotidianamente, as rezas de início de turno, percebi que todos os estudantes acabam participando, mesmo aqueles que tentam evitar a participação, seja por motivos religiosos, seja por simples falta de vontade. Alguns dos estudantes fazem parte da roda, rezam, mas permanecem efetivamente em silêncio na hora de entoar os cantos para os encantados, seja por orientação religiosa, ou por desconhecimento dos cantos. Outros, contudo, conhecem bem os cantos, cantam e gostam de participar da reza de abertura. Por exemplo, dois irmãos de família de pequenos produtores comentaram gostar da roda
26. Ver também Ferreira (2011: 106) e Reis (2017: 64-66). 
de abertura e compararam-na, positivamente, à obrigação de entoar o hino nacional nos colégios da cidade anteriormente frequentados. Segundo um deles:

\begin{abstract}
Acho que a reza é melhor do que o hino nacional porque a gente está rezando, está pedindo para dar proteção, pedir as coisas. Até quando vou fazer uma prova, peço logo a Deus, na abertura, para ver se ele puder ajudar em alguma coisa. Têm os cantos, coisas diferentes que em outras escolas a gente não vê. Bem diferente. Têm significados diferentes.
\end{abstract}

Importa, ainda, compreender a formação desses estudantes sobre seus direitos e os direitos indígenas, com vistas à redução de preconceitos de parte a parte, de modo a permitir que tal formação possa ser ao mesmo tempo um meio de abertura para o outro não indígena, de defesa da comunidade mediante a conquista de novos aliados e de possibilidade, para uns e outros, de um melhor convívio interétnico e de promoção social mediante a escolarização.

A diretora Magnólia observa, com propriedade, que geralmente o estudante não indígena que ingressa no colégio está também vinculado a algum movimento: "a gente tem mais pessoas que são da luta mesmo, mesmo não sendo índios, mas eles lutam pelo direito deles, eles têm uma luta parecida". Sendo assim, ela acrescenta que os professores indígenas, além de ensinarem os conteúdos das diferentes disciplinas, capacitam também os não indígenas sobre seus direitos na base da luta indígena: "O que a gente faz? Porque a gente faz? Qual é a lei que ampara? [...] Então fala isso para eles, para eles também ter como se defender lá, quando alguém lá falar deles". Neste sentido, uma estudante indígena ressalta que:

\begin{abstract}
a questão da luta indígena, da luta pela terra sempre vem à tona, fora da sala ou dentro da sala, sempre vem à tona. [...] A luta da terra nunca teve assim uma matéria diretamente mas sim sempre cai quando a gente está conversando sobre um assunto de história por exemplo, da época medieval, dos senhores feudais que a gente fez uma pequena comparação com os fazendeiros de hoje.
\end{abstract}

O representante do Assentamento Nova Jerusalém comentou que antes mesmo de conhecer o cacique Babau pessoalmente, o defendia das pessoas que diziam "esses índios são todos ladrões". Ao contrário, ele disse: "eu vejo que é um camarada que luta". Entende que os indígenas não estão tomando terra de ninguém, mas estão apenas 
lutando pelos seus direitos. Segundo ele, quando as pessoas não conhecem a luta, discriminam. Eles também são chamados de "ladrões de terra" por serem do Movimento Sem Terra.

A educação escolar indígena é, portanto, um âmbito onde se cruzam conhecimentos e lógicas distintas, contribuindo para a preservação dos saberes e lógicas tradicionais e, ao mesmo tempo, buscando aprimorar aqueles da sociedade dominante, no intuito de reverter a situação de subalternidade. Rufino (2018: 74) fala de pedagogia das encruzilhadas ${ }^{27}$ como sendo "a reinvenção dos seres, a partir dos cacos desmantelados, o reposicionamento das memórias e a justiça cognitiva diante do trauma e das ações de violência produzidas pelo colonialismo". O autor desenvolve o conceito de pedagogia das encruzilhadas junto com Simas (Simas; Rufino, 2018: 36 e 78), onde "a gira se firma a partir de muitas lógicas" [...] "encruzilhando experiências de alargamento das percepções do mundo".

A educação escolar indígena, ou melhor dito, o projeto desenvolvido no âmbito desta educação orientado pelos encantados, é, então, uma importante ferramenta para que a comunidade obtenha mais autonomia. Conforme Baniwa (2011: 288), tal educação representa "uma possibilidade de empoderamento político para dentro e para fora da comunidade", bem como "de construir conhecimentos e experiências com vistas à autogestão das aldeias e das Terras Indígenas [...]”. Segundo os anciões e o cacique tupinambás, os estudantes devem sair do Colégio dominando a "lógica do branco" sem perder de vista a própria cultura, acessar a educação superior, ocupar esse espaço e diplomar-se em áreas de conhecimento úteis para a luta e o desenvolvimento dos projetos da comunidade: saúde, direito, administração, comunicação, línguas, entre outros.

$\mathrm{Na}$ Serra do Padeiro, a transmissão de saberes, tanto aquela de caráter informal quanto aquela sistematizada no âmbito da educação escolar indígena, é indissociável das ações dos encantados, guardiões da memória do seu povo.

Esse modelo escolar está contribuindo para formar crianças, jovens e adultos - indígenas e não indígenas sob novas bases, na contramão do que preconiza a lógica governamental e a lógica de mercado. E disso os Tupinambá parecem estar conscientes. O cacique Babau, não tem dúvida de que o modo de vida tupinambá de acordo com a va-
27. Disponível em: https:// www.e-publicacoes.uerj. br/index.php/periferia/ article/view/31504/24540. 
riante Serra do Padeiro está, gradativamente, invertendo as posições no contexto regional: ao invés de devedores dos poderes externos, dá-se o contrário, isto é, o modo de produção e reprodução tupinambá colabora, decisivamente, para a produção e reprodução regional, seja através da preservação do ambiente (nascentes e matas ciliares), seja mediante a sua cosmologia (espiritualidade). Seja, finalmente, através do seu projeto de educação interétnica e intercultural.

De fato, as evidências reunidas apontam para uma experiência intercultural que pode representar um modelo a ser seguido - exportado, segundo o cacique Babau - além dos limites da comunidade indígena. "[...] O mundo é uma questão da gente ir ensinando um ao outro. [...] Cada hora, as coisas são diferentes e uma escola existe para trabalhar exatamente isso: a evolução do dia a dia”. O pequeno excerto talvez possa sintetizar o projeto de educação escolar indígena na Serra do Padeiro pela voz autorizada do seu cacique. 


\section{Referências}

Agier, Michel; Carvalho, Maria Rosário G. de. 1994. "Nation, race, culture: les mouvements noirs et indiens au Brésil”. Cahiers de l’Amérique Latine 7: 107-124. https://horizon.documentation.ird. fr/exl-doc/pleins_textes/pleins_textes_7/b_fdi_57-58/010025451.pdf.

Alarcon, Daniela Fernandes. 2013. O retorno da terra: as retomadas na aldeia Tupinambá da Serra do Padeiro, sul da Bahia. Dissertação de Mestrado, UnB, Brasília, DF, Brasil.

Alarcon, Daniela Fernandes. "Biografia - João de Nô". In: Os Brasis E Suas Memórias. https:// osbrasisesuasmemorias.com.br/biografia-joao-de-no/.

Baniwa Luciano, Gersem José dos Santos. 2011. Educação para manejo e domesticação do mundo: entre a escola ideal e a escola real Os dilemas da educação escolar indígena no Alto Rio Negro. Tese de Doutorado, Unb, Brasília, DF, Brasil.

Benites, Tonico. 2012. A escola na ótica dos Ava Kaiowá: impactos e interpretações indígenas. Rio de Janeiro: Contra Capa.

Cascudo, Luís da Câmara. 1998. Dicionário do folclore brasileiro. 9. ed. Rio de Janeiro: Ediouro.

Couto, Patricia Navarro de Almeida. 2008. Morada dos encantados: Identidade e religiosidade entre os Tupinambá da Serra do Padeiro, Buerarema, BA. Dissertação de Mestrado, UFBA, Salvador, BA, Brasil.

Prandi, Reginaldo. 2003. Mitologia dos Orixás. São Paulo: Companhia das Letras.

Quadros, Jéssica Silva de. 2018. Pisando na terra de Tupinambá. O encontro do povo Bantu na morada dos encantados. Trabalho de conclusão de curso de Especialização, UFBA, Salvador, BA, Brasil.

Simas, Luiz Antonio; Rufino, Luiz. 2018. A ciência encantada das macumbas. Rio de Janeiro: Mórula.

Surrallés, Alexandre. 2017. "Human rights for nonhumans". Hau: Journal of Ethnographic Theory 7 (3): 211-235. https://www.journals.uchicago.edu/doi/pdfplus/10.14318/hau7.3.013.

Ubinger, Helen Catalina. 2012. Os Tupinambá da Serra do Padeiro: Religiosidade e territorialidade na luta pela terra indígena. Dissertação de Mestrado, UFBA, Salvador, BA, Brasil.

\section{Vídeos:}

Alarcon, Daniela Ferandes; Tupinambá - O Retorno da Terra (24,58'), 2015. https://vimeo. com/126566470. 